\title{
Temperature investigation and modeling on the Filchner-Ronne Ice Shelf, Antarctica
}

\author{
K. Grosteld) AND F. Thyssen \\ Institut fü Geophysik, Forschungsstelle für physikalische Glaziologie der Westfälischen Wilhelms-Universität Münster, \\ D-48149 Münsler, Genman!
}

\begin{abstract}
ABS'TRACT. During the Gcrman Antarctic Expedition ficld scason 1989-90, hotwater drilling was undertaken on the Filchner-Ronne Ice Shelf (FRIS) at $77^{\circ} \mathrm{S} 52^{\circ} \mathrm{W}$ to investigate the temperature-depth profile and the bottom-melting ratc, which are significant parameters for mass- and energy-balance studies of the ice shelf. Remeasurements of installed chains in 1991-92 yielded reliable results.

Taking glaciological, geodetic and geophysical data on a flowline through the central part of FRIS, we developed a two-dimensional thermal model to reconstruct the measurements from a steady-state temperature depth profile about $550 \mathrm{~km}$ upstream on Möllereisstrom. Considering mass and energy conservation, a basal layer of $350 \mathrm{~m}$ of marine ice was calculated with thermal properties, depending on salinity and temperature. In arcas with strong basal freezing, almost isothermal depth profiles in the marine ice layer are derived. Further downstrcam, in areas of basal melting, a nearly cubic temperature-depth profile is observed.
\end{abstract}

\section{INTRODUCTION}

The greater part of the Antarctic coastline is fringed by floating ice shelves, which comprise $11 \%$ of the total area of Antarctica (Drewry, 1983). About one-third of the inland ice drains into the two largest icc shelves, the Filchner-Ronne Ice Shelf (FRIS) and the Ross Icc Shelf. From two points of view, jece shelves play a crucial role in the global climatic system:

On the one hand, the inland ice discharges its ice masses into the ice shelves. Assuming steady-state conditions over large time-scales, ice shelves represent sensitive indicators for climatic-induced instabilities of the ice sheet (e.g. Mercer, 1978; Van der Veen, 1985).

On the other hand, basal melting and freezing of ice shelves is a significant parameter in the formation of Antarctic Bottom Water, which spreads far into the Northern Hemisphere and ventilates the deep part of the Norld Oceans (Farbach and others, 1991).

For all this, ficld investigations of glaciologically relevant parameters like ice thickness, flow velocity, accumulation rate, tempcrature, etc., as well as modcling of ice flow, mass and energy balance are necessary tools for a better understanding of the mass balance and dynamics of the Antarctic ice shelves.

For more than 10 years, special interest was focused on the investigation of the central part of the FRIS with cxtensive glaciological field work Robin and others, 1983, Crabtree and Doake, 1986; Thyssen, 1986: Engelhardt and Determann, 1987; Pozdeyev and Kurinin, 1987; Thyssen, 1988). One main result of these investigations was an up to $400 \mathrm{~m}$ thick marine ice layer underlying the meteoric ice, which drains from the West Antarctic ice shect. This marinc layer is a significant mass-balance factor and was specially investigated during the German Antarctic Expedition 198990 with radio-echo soundings (Thyssen and others, 1992; Blindow, 1994) and ice-core drillings (Oerter and others, 1992a). In addition, scveral hot-water drillings were made to investigate the temperature-depth function and the bottom-melting rate by means of temperature sensors and time-domain reflectometry (TDR) devices. Re-measurements of the installed chains in 1991-92 gave reliable results for the bottommelting rate over 2 years (Grosfeld, 1992; Grosfeld and others, in press .

For a flowline through the central part of the FRIS, we will try to demonstrate in this paper that especially the tempcrature-depth function is strongly affected by the basal-accretion processes. A comparison with measured temperature-depth data is given. Since temperature is a significant parameter for the flow properties of ice, it influences its dynamic behaviour. In previous studies concerning the flow of FRIS Lange and MacAycal, 1988; Determann, 1991), a mean value for the temperature-dependent flow parameter was used, which is synonymous to an averaging of the rheological propertics over the whole ice thickness. This is in contrast to the amount of freczing of marine ice in the central part of the FRIS, since basal freezing produces a heat input and an increase in the depth-avcraged tempcrature, while basal melting erodes the warmest part of the ice column next to the ice/ocean interface and reduces the mean temperature. 


\section{TEMPERATURE INVESTIGATION}

In 1990, five chains with $64100 \Omega$ platinum RTD temperature sensors were frozen into the $239 \pm 2 \mathrm{~m}$ thick ice shelf in the vicinity of point 61 (Fig. 1) on IRIS. Due to logistical reasons, the hot-water drillings were performed in the ice-edge region of the ice shelf; $50 \mathrm{~km}$ northwest of Filchner Station, while the main region that is affected by the accumulation of almost $100 \mathrm{~m}$ marine ice is located further to the south. The distribution of marine ice and its thickness was derived by Thyssen (1988) and Thyssen and others (1992) from radio-echo soundings and surface-clevation mcasurements. In the investigated area, the meteoric and marine ice was 86 and $.153 \mathrm{~m}$ thick, respectively.

A temperature-depth profile from the remeasurement in 1992 is shown in Figure 2 (solid line). The upper $8 \mathrm{~m}$ of the temperature profile are influenced by the warm summer period and show a steep negative gradient. Further down, the temperature profile shows a uniform gradient. There is no change in the temperature gradient at the boundary from meteoric to marine ice, indicating similar heat conductivities and therefore the same thermal properties for both media. Only the lowest $25 \mathrm{~m}$ above the icc-shelf bottom are influcnced by bottom-melting processes and show a steeper temperature gradient. The basal ice is eroded by melting processes so fast that heat conduction cannot follow and the temperature-depth function shows a large difference over a small depth range. The influence of the heat input from bottom accretion in the central part of the FRIS, which causes an inversion in the temperature gradient and an almost isothermal basal

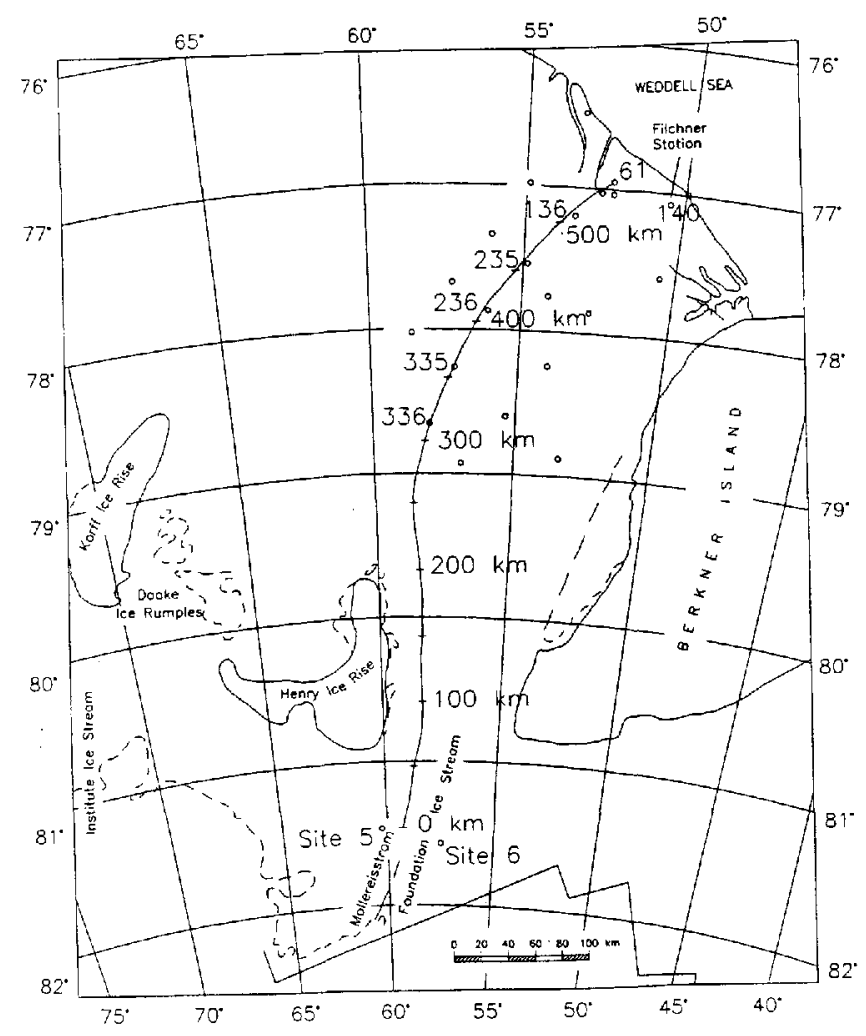

Fig. 1. Map of the central part of FRIS (from Srithinbank and others, 1988) with calculated floweline for thermal modeling and geodetic observation points. layer of warm ice with freczing-point temperatures, vanishes at the drill site, $30 \mathrm{~km}$ from the ice edge. The temperature profile is a typical cubic one, indicating basal-melting processes.

About $150 \mathrm{~km}$ upstream of the hot-water drillings, a temperature-depth profile was mcasured by Ocrter and others (1992b) in a core drilling at point 236. The drillhole reached down to a depth of $320.7 \mathrm{~m}$, whereas the total ice thickness was calculated to be $422 \mathrm{~m}$ from surface elevation and isostatic-equilibrium conditions (Thyssen, 1988). The transition from meteoric to marine ice was detected at a depth of $153 \mathrm{~m}$, which had already been determincd by electromagnetic soundings during the 198990 field season personal communication from $\mathrm{N}$. Blindow) and is the same as the depth at point 61 . The temperature-depth profile (Fig. 2, broken line) shows an S-shaped form, due to bottom freezing of warm marine ice. For the same reason as in the case of basal melting, heat-conduction processes are too slow for temperature compensation between the warm basal ice and the colder glacier icc, so that advection processes dominate. The typical S-shaped temperature depth profile has already been described by Morgan 1972 for the Amery Ice Shelf, where a basal layer of $158 \mathrm{~m}$ of marine ice was found. Point 236 is located at the northern boundary of a heavily crevassed arca north of Henry Ice Rise. This area probably conforms with the region of main basal freezing as it has been outlined by Thyssen and others (1992) from intensive EMR soundings. For the modeling of the energy balance on a flowline starting on Möllereisstrom through the central part of FRIS, passing point 236 and point 61 , we expect that the S-shape of the

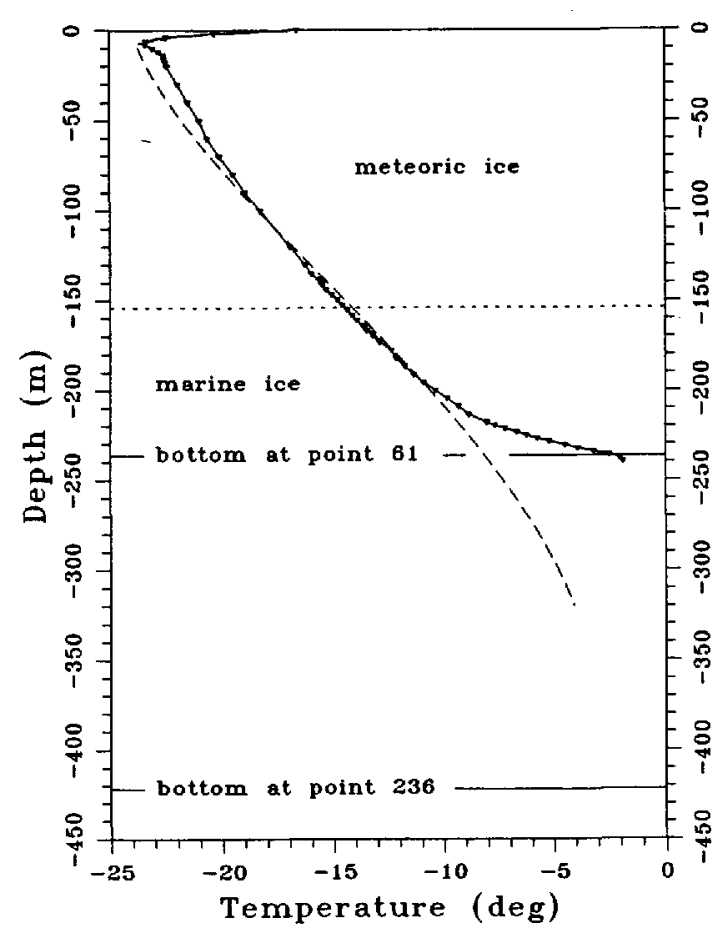

Fig. 2. Measured temperature-depth profiles at point 61 (solid line) (Grosfeld and others, in press) and point 236 (broken line) (Oerter and others, 1992b). The horizontal solid line indicates the ice-shelf bottom at the trio locations, while the dolled horizonlal line indicales the boundary between metenrir to marine ice. 
temperature depth profile will strongly increase in the region of the main basal accumulation. Further north, the S-shape will vanish due to heat-conduction processes and further downstream duc to bottom-mclting processes.

In the next section, a two-dimensional model for the calculation of the energy balance under consideration for mass conservation is described.

\section{MODEL THEORY}

The general cquation of energy conservation in a homogencous medium can be described as (Carslaw and Jaeger, 1959):

$$
\frac{\partial T}{\partial t}=\frac{1}{\rho c_{\mathrm{p}}} \nabla(k \nabla T)-\vec{u} \nabla T+\frac{Q}{\rho c_{\mathrm{p}}}
$$

where $T$ is temperature; $t$ is time; $\rho, c_{\mathrm{p}}$ and $k$ are the density, specific-heat capacity and thermal conductivity of the medium, whereas $\rho, k$ are functions of space $(x, y, z) ; \vec{u}$ is the three-dimensional velocity vector with its Cartesian components $u, v, w$, and $Q$ is the rate of internal-heat production. Using this description of energy conservation, conductive terms, as well as advective terms, are considered.

For the determination of the temperature field for the special problem of FRIS, a scparation in a meteoric and in a marine layer was chosen for consideration of their different thermal properties.

In the meteoric ice, the process of firn densification influences the temperature-depth function in the upper $100 \mathrm{~m}$ of the ice column. This effect has been regarded using functions of depth for density given by Herron and Langway (1980) and for thermal conductivity given by Van Dusen (1929) or Schwerdteger (1963a), respectively. The variation of the thermal properties with temperature has not been taken into consideration, since this effect is small compared with the firn densification in the upper layers and the influence of basal freczing in the lower part of the ice column.

In addition, further simplifications, resulting from the special gcometry of ice shelves, are applied. Sanderson and Doake (1979) have pointed out that in nearly all cases vertical shear in ice shelves is negligible. A vertical column of ice remains vertical, far away from grounded regions, so that horizontal components of velocity and strain rate can be treated as depth-independent variables. In this case, the horizontal temperature gradients are negligible compared to the vertical gradient. Horizontal diffusion terms vanish, while the vertical diffusion term dominates. Since the only significant source of internalheat production is strain heating, the $Q$ term is also negligible for ice shelves. From the condition of a depthindependent velocity, another simplification can be determined. The derivative $\partial T / \partial t$ can be regarded as a local derivative, moving with the column, so that the horizontal advective term is implicitly incorporated (Paterson, 1981). With the definition of the thermal diffusivity:

$$
\kappa=\frac{k}{\rho c_{\mathrm{p}}}
$$

Lquation (1) changes to

$$
\frac{\partial T}{\partial t}=\kappa \frac{\partial^{2} T}{\partial z^{2}}+\left[\frac{1}{\rho c_{\mathrm{p}}} \frac{\partial k \partial \rho}{\partial \rho \partial z}-w\right] \frac{\partial T}{\partial z} .
$$

The vertical-vclocity component $w$ controlling the advective-heat transport is a function of depth and can be dcrived by integrating the vertical strain rate $\dot{\varepsilon}_{z z}=-\left(\dot{\varepsilon}_{x x}+\dot{\varepsilon}_{y y}\right)$ over the ice thickness, which is given by the condition of incompressibility. $w$ is a composed parameter and given at the ice surface by the accumulation rate $\dot{a}_{\mathrm{i}}\left(\dot{a}_{\mathrm{i}}=\dot{a} / \rho\right)$, at the ice bottom by the melting or freezing rate $m$ ( $m<0$ melting; $m>0$ freezing), and by strain thinning within the ice column. The origin of the coordinate systcm was set to the ice surface, where $x$ points into the direction of flow, $y$ and $z$ were chosen to make the system righthanded, with $z$ positive downwards.

The vertical velocity in depth $z$ is Robin, 1955; MacAyeal and Thomas, 1986):

$$
w(z)=\left(1-\frac{z}{H}\right) \dot{a}_{\mathrm{i}}+z \dot{\varepsilon}_{z z}+\frac{z}{H} m
$$

where $H$ is the ice thickness.

In contrast to the meteoric icc, the marinc ice layer is formed in the water column underneath the ice shelf by crystallization of ice platelets accumulating at the bottom of the icc shelf. This process is causcd by a large circulation system in the water column (Hellmer and Olbers, 1989, 1991; Jenkins, 1991; and can be explained by an ice-pump model, which was first introduced by Robin (1979) and Lewis and Perkin (1986). The ice platelets first form a slushy layer at the ice-shelf bottom (Thyssen. 1986; Fngelhardt and Determann, 1987), which then condense during its accretion to a compact layer. The enclosed liquid-brine pockets drain during the compaction process into the sea and thus a marine-ice layer with very low salinities in the upper parts is built (Oerter and others, 1992a).

To consider these processes in our temperature model, we subdivided the marine ice into two layers. In the lowest part of the ice shelf, a slushy layer with thermal properties depending on salinity and temperaturc was chosen. Here, we used a thermodynamic model for sea-ice formation comparable to that described by Lntersteiner (1964) and Maykut and Untersteiner (1971), who gave the following equations for the conductivity $k_{\mathrm{s}}$ :

$$
k_{\mathrm{s}}=k_{\mathrm{i}}+\frac{\beta S(z)}{T-273}
$$

and the product of density and specific heat $\left(\rho c_{1}\right)_{\mathrm{s}}$ :

$$
\left(\rho c_{\mathrm{p}}\right)_{\mathrm{s}}=\left(\rho c_{\mathrm{p}}\right)_{\mathrm{i}}+\frac{\gamma S(z)}{(T-273)^{2}}
$$

The subscripts $\mathrm{i}$ and $\mathrm{s}$ refer to pure ice and marine ice, respectively, where $k_{\mathrm{i}}=2.10 \mathrm{~W} \mathrm{~m}^{-1} \mathrm{~K}^{-1} ; \beta=0.117$ $\mathrm{W} \mathrm{m}^{2} \mathrm{~kg}^{-1} ; S(z)$ is the salinity in $\mathrm{kg} \mathrm{m}^{-3} ; T$ is the temperature in $\mathrm{K} ;\left(\rho c_{\mathrm{p}}\right)_{\mathrm{i}}=1.842 \times 10^{6} \mathrm{~J} \mathrm{~m}^{3} \mathrm{~K}{ }^{1}$; and $\gamma=17.169 \times 10^{6} \mathrm{~J} \mathrm{~K} \mathrm{~kg}^{-1}$. The second laycr above the slushy layer consists of old desalinated ice with a constant salinity, so that only the temperature-dependence of the thermal properties has to be regarded. 
Another two equations were introduced into our model. From basal freezing, the slushy layer may bc influenced by crystallization heat. Since there is no definite temperature for the phase change from the fluid to the solid state, the latent heat of fusion $L_{\mathrm{s}}$ has to be described as a function of temperature and salinity. According to $\operatorname{Yen}(1981), L_{\mathrm{s}}$ is:

$$
\begin{aligned}
L_{\mathrm{s}}=4.1868(79.68 & -0.505(T-273)-27.3 S(z) \\
& \left.+4311.5 \frac{S(z)}{T-273}\right)
\end{aligned}
$$

In addition, the density of marine ice is a function of - salinity, tempcrature and air-bubble content (Schwerdtfeger, 1963b). From core samples of the marine ice of FRIS, we know that this ice is clear and alrcady frec of bubbles (Oerter and others, 1992a), so that $\rho_{\mathrm{s}}$ is:

$$
\rho_{\mathrm{s}}=(1-\alpha)\left(1-\frac{4.56 S(z)}{T-273}\right) \rho_{\mathrm{i}}
$$

with the air-bubble content $\alpha=0$ and the density of pure ice $\rho_{\mathrm{i}}=917 \mathrm{~kg} \mathrm{~m}^{-3}$.

Summarizing these equations, the amount of internal energy due to the formation of icc crystals or melting of ice at the icc-shelf bottom is:

$$
Q=\rho_{\mathrm{s}} L_{\mathrm{s}} m
$$

This description of the influence of crystallization processes at the bottom of the ice shelf can be regarded as an internal-heat source in the heat-conduction cquation. Since the relcase of latent heat within the slushy layer is already regarded in the definition of conductivity and volune heat in dependence of salinity and temperature, it is better to be considered in the thermal-boundary condition at the ice/sea-water interface. Heat conduction and advection are the major processes in the slushy layer. Thus, the encrgy equation for the upper layers of old, desalinated marine ice is:

$$
\begin{aligned}
\frac{\partial T}{\partial t}= & \frac{k_{\mathrm{s}}}{\left(\rho c_{\mathrm{p}}\right)_{\mathrm{s}}} \frac{\partial^{2} T}{\partial z^{2}}-w \frac{\partial T}{\partial z} \\
& -\frac{1}{\left(\rho c_{\mathrm{p}}\right)_{\mathrm{s}}} \frac{\beta S}{(T-273)^{2}}\left(\frac{\partial T}{\partial z}\right)^{2}
\end{aligned}
$$

and for the slushy layer:

$$
\begin{aligned}
\frac{\partial T}{\partial t}= & \frac{k_{\mathrm{s}}}{\left(\rho c_{\mathrm{p}}\right)_{\mathrm{s}}} \frac{\partial^{2} T}{\partial z^{2}}+\left[\frac{1}{\left(\rho c_{\mathrm{p}}\right)_{\mathrm{s}}} \frac{\beta}{T-273} \frac{\partial S}{\partial z}-w\right] \cdot \frac{\partial T}{\partial z} \\
& -\frac{1}{\left(\rho c_{\mathrm{p}}\right)_{\mathrm{s}}} \frac{\beta S}{(T-273)^{2}}\left(\frac{\partial T}{\partial z}\right)^{2} .
\end{aligned}
$$

Equations (10) and (11) come from Equations (3), (5) and $(6)$.

The salinity profile in the slushy layer can be taken as an cxponential function according to Kipfstuhl (1991), whereas the thickness of the slushy layer $\left(H_{\mathrm{sl}}\right)$ scale the values:
$S(z)= \begin{cases}S_{0} & \text { for } z_{\mathrm{mct} / \mathrm{mar}}<z \leq z_{\mathrm{mar} / \mathrm{sl}} \\ S_{0} \operatorname{cxp}\left[a\left(z-z_{\mathrm{mar} / \mathrm{sl}}\right)\right] & \text { for } z_{\mathrm{mar} / \mathrm{sl}}<z \leq H\end{cases}$

$S_{0}$ denotes the salinity of the old desalinated ice with $0.1 \%$, according to the analysis of the core samples (Oerter and others, 1992a), and

$$
a=\frac{1}{H_{\mathrm{sl}}} \ln \left(\frac{10 \%}{0.1 \%}\right)
$$

is the coefficient of the exponential function. The parameters $z_{\text {mel/mar }}$ and $z_{\text {mar/si }}$ describe the depth of the meteoric to marine-ice interface and from the old marine ice to the slushy layer. The maximum salinity at the iceshelf bottom was set at $10 \%$.

\section{NUMERICAL SOLUTION AND BOUNDARY GONDITIONS}

The differential equations describing the temperature regime of a flowline through the central part of FRIS were solved by means of the finite-difference method using normalized, dimensionless coordinates for depth and time derivatives. We used the actual ice thickness $H$ of the ice column as the length scale, so that $z^{*}=$ $z /\left(H\left(t^{*}\right)\right)$, with a dimensionless time-scale $t^{*}=B t$, where $B=|1|\left[\mathrm{s}^{-1}\right]$. With this definition, the vertical-scale transforms to $z^{*}=0$ at the ice surface and $z^{*}=1$ at the ice-shelf bottom. In addicion, a pseudo-advective term $-z^{*} \dot{H}\left(t^{*}\right) \frac{\partial}{\partial z^{*}}$ is introduced into the scaled energy equation, regarding the dynamic change in the vertical grid spacing that is caused by the thickness variation along the flowline while the number of grid points remains constant. We used an explicit scheme for the approximation of the differential equation with centered finite-differences for the depth derivatives and a forward difference form for the time derivative. The explicit scheme is characterized by a strong stability condition and given as $\kappa \Delta t / \Delta z^{2} \leq 0.5$, where $\Delta t$ and $\Delta z$ are the grid steps in time and depth.

The thermal-boundary conditions of the problem are given in Dirichlet's form at the ice surface by the mean annual temperature $T_{m}$, which is influenced by a seasonal variation. $T(z=0, t)$ is:

$$
T(z=0, t)=T_{0}(t)=T_{\mathrm{m}} .
$$

The influence of a spccial scasonal phase, which can be described by the additional term $T_{\mathrm{s}} \sin \left(\omega t^{\prime}\right)$ in the boundary condition, can be regarded for a composition of measured data with the calculated model. Here $T_{\mathrm{s}}$ and $\omega / 2 \pi$ describe the amplitude and frequency of the seasonal variation and $t^{\prime}$ the special seasonal phase, at which the measurement was performed. At the bottom, the boundary condition is described by the freezing point $T_{\mathrm{f}}$ of sea watcr at the ice/sea-water interface (Foldvik and Kvinge, 1974):

$$
T(z=H, t)=T_{\mathrm{b}}(t)=T_{\mathrm{f}}=a S_{\mathrm{b}}+b-c P .
$$


Here, $a=-0.057^{\circ} \mathrm{C}, \quad b=0.0939^{\circ} \mathrm{C}$ and $c=7.64 \times$ $10^{-40} \mathrm{Cdbar}^{-1}, S_{\mathrm{b}}$ is the salinity of the sea water and $P$ is the pressure at the interface in dbar. The interaction between ice shelf and ocean is important for the mclting or freczing of the ice shelf as well as the formation of Ice Shell Water, which influences the freezing point. Hence, for its calculation, the heat and salt fluxes at this interfacc are important paramelers and have been described by Hellmer and Olbers (1989) and Scheduikat and Olbers (1990). The heat balance is given by:

$$
q_{\mathrm{w}}^{\mathrm{T}}=q_{\mathrm{i}}^{\mathrm{T}}+q_{\mathrm{b}}^{\mathrm{T}}
$$

where $q_{w}{ }^{\mathrm{T}}$ is the total heat flux crossing the interface. According to Welander $(1977), q_{w}{ }^{\top}$ is proportional to the temperature difference between the sea water and the iceshelf base $T_{\mathrm{w}}-T_{\mathrm{b}}$ :

$$
q_{\mathrm{w}}^{\mathrm{T}}=\rho_{\mathrm{w}} c_{\mathrm{pw}} \gamma_{\mathrm{T}}\left(T_{\mathrm{b}}-T_{\mathrm{w}}\right) .
$$

$\rho_{w}=1028 \mathrm{kgm}^{3}$ is the sea-water density, which is determined by occanographic measurements at the ice edge of FRIS (Foldvik and others, 1985); $c_{\mathrm{pw}}=4000$ $\mathrm{J} \mathrm{kg}^{-1} \mathrm{~K}^{-1}$ is the specific-heat capacity of sea water; and $\gamma_{\Gamma}=1 \times 10^{4} \mathrm{~ms}^{1}$ is the turbulent-heat exchange coefficient. $q_{\mathrm{w}}{ }^{\mathrm{T}}$ is divided into the heat flux at the ice/sea-water interface duc to melting or freczing (cf. Lquation (9)):

$$
q_{\mathrm{b}}^{\mathrm{T}}=\rho_{\mathrm{s}} L_{\mathrm{s}} m
$$

and into heat conduction through the ice:

$$
q_{\mathrm{i}}^{\mathrm{T}}=k\left(\frac{\mathrm{d} T}{\mathrm{~d} z}\right)_{z=\text { slush/sea watcr }}
$$

The interaction of ice and sea water also depends on the salt flux, where the total salt flux $q_{\mathrm{w}} \mathrm{S}$ is cqual to the flux $q_{\mathrm{b}}{ }^{\mathrm{S}}$, caused by melting or freezing:

$$
q_{\mathrm{w}}{ }^{\mathrm{S}}=\rho_{\mathrm{w}} \gamma_{\mathrm{s}}\left(S_{\mathrm{b}}-S_{\mathrm{w}}\right)=\rho_{\mathrm{i}} S_{\mathrm{b}} m=q_{\mathrm{b}}{ }^{\mathrm{S}} .
$$

Here $S_{\mathrm{b}}$ and $S_{\mathrm{w}}$ are the salinities at the ice-shelf base and the ocean, and $\gamma_{\mathrm{s}}=5.05 \times 10^{7} \mathrm{~ms}^{1}$ is the turbulent saltexchange coefficient.

Using this set of equations, the basal temperature $T_{b}$ and the melting/freezing rate $m$ can be derived with known values for $T_{i}, T_{w}, S_{w}$. The values for $T_{w}$ and $S_{w}$ can be taken from an ocean model conducted by Hellmer and Olbers (1989, 1991).

Since, in the freczing domain, the build-up of the marine ice body comes mainly from the formation of frazil ice in the water column underneath the ice column, we need to have a more complex oceanographic model 10 calculate the real basal-accretion rate. For this reason, we derived the melting/freczing rate for the central part of FRIS in areas with marine ice from the continuity equation for mass conservation (e.g. Crary and others, 1962):

$$
0=u \frac{\partial H}{\partial x}+v \frac{\partial H}{\partial y}-\dot{\varepsilon}_{z z} H-\dot{a}_{\mathrm{i}}-m .
$$

By assuming the model is exactly on a flowline, the velocity components perpendicular to the direction of flow are zero. As internal shear is negligible, the continuity equation can be separated into two equations, one for the meteoric part and one for the marine part:

$$
\begin{aligned}
& \dot{a}_{\mathrm{i}}=u \frac{\partial H_{\mathrm{met}}}{\partial x}-\dot{\varepsilon}_{z z} H_{\mathrm{met}} \\
& m=u \frac{\partial H_{\mathrm{mar}}}{\partial x}-\dot{\varepsilon}_{z z} H_{\mathrm{mar}}
\end{aligned}
$$

Dcriving accumulation rate $\dot{a}_{\mathrm{i}}$, meteoric ice thickness $H_{\text {met }}$ and marine-ice thickness $H_{\text {mar }}$ along a flowline by geophysical and glaciological measurements, the vertical strain rate $\dot{\varepsilon}_{z z}$ can be calculated from Equation (21). Together with Equation (22), it is possible to obtain the basal melting/freczing rate.

\section{RESULTS OF THE THERMAL MODEL ON A FLOWLINE THROUGH THE CENTRAL PART OF FRIS}

For the determination of the temperature regime in the central part of FRIS, the thermal model was applicd to a flowline through the central part, starting on Möllereisstrom south of Henry Ice Rise and Berkner Island in the vicinity of site 5, passing the geodetic points 336-335236-235-136, and ending at point 61 (Fig. 1). The flowline was calculated from a two-dimensional ice-flow model described by Determann (1991). The boundary values at the ice surface and bottom, as well as the thickness distribution of meteoric and marine ice, were taken from geophysical data (Thyssen and others, 1992), geodetic data (Determann, 1991; Ritter and Karsten, 1991; Möller and others, 1992), glaciological data (Graf and others, 1991; Kipfstuhl and Oerter, 1991; Morris and Vaughan, 1991), and occanographic modeling (Hellmer and Olbers, 1991). The initial temperature profile was assumed to be that of a steady state, according to Crary (1961), with melting conditions at the ice-shelf base. This assumption can be confirmed by radio-echo soundings in this area. The detected bottom reflections show large amplitudes with mirror-like conditions, indicating basalmelting conditions and an absence of marine ice (Crabtree and Doake, 1986; Thyssen, 1988).

For the numerical simulation, the ice thickness at site 5 was measured as $1016 \mathrm{~m}$. It was divided into 255 steps with an increment of $4 \mathrm{~m}$. The duration of the simulation. along the flowline was calculated from the velocity ficld as $1362 \mathrm{a}$. The time increment was set at $0.01 \mathrm{a}$, which fulfilled the stability condition with its decreasing depth increment during the whole simulation. At the end of the simulation, an ice thickness of $235 \mathrm{~m}$ was reached.

In Figure 3, an overview of the input data along the flowline is shown. The circles correspond to measured data at fixed geodetic points, while flow-velocity data were taken at a distance of about $2 \mathrm{~km}$ from the flowline calculated by Determann (1991). For equidistant grid points, the data were additionally interpolated by a spline algorithm. The vertical strain rate was calculated from data in the area of the basal marine layer with a separated continuity equation (cf. Equation (21)). The data show a negative gradient in 

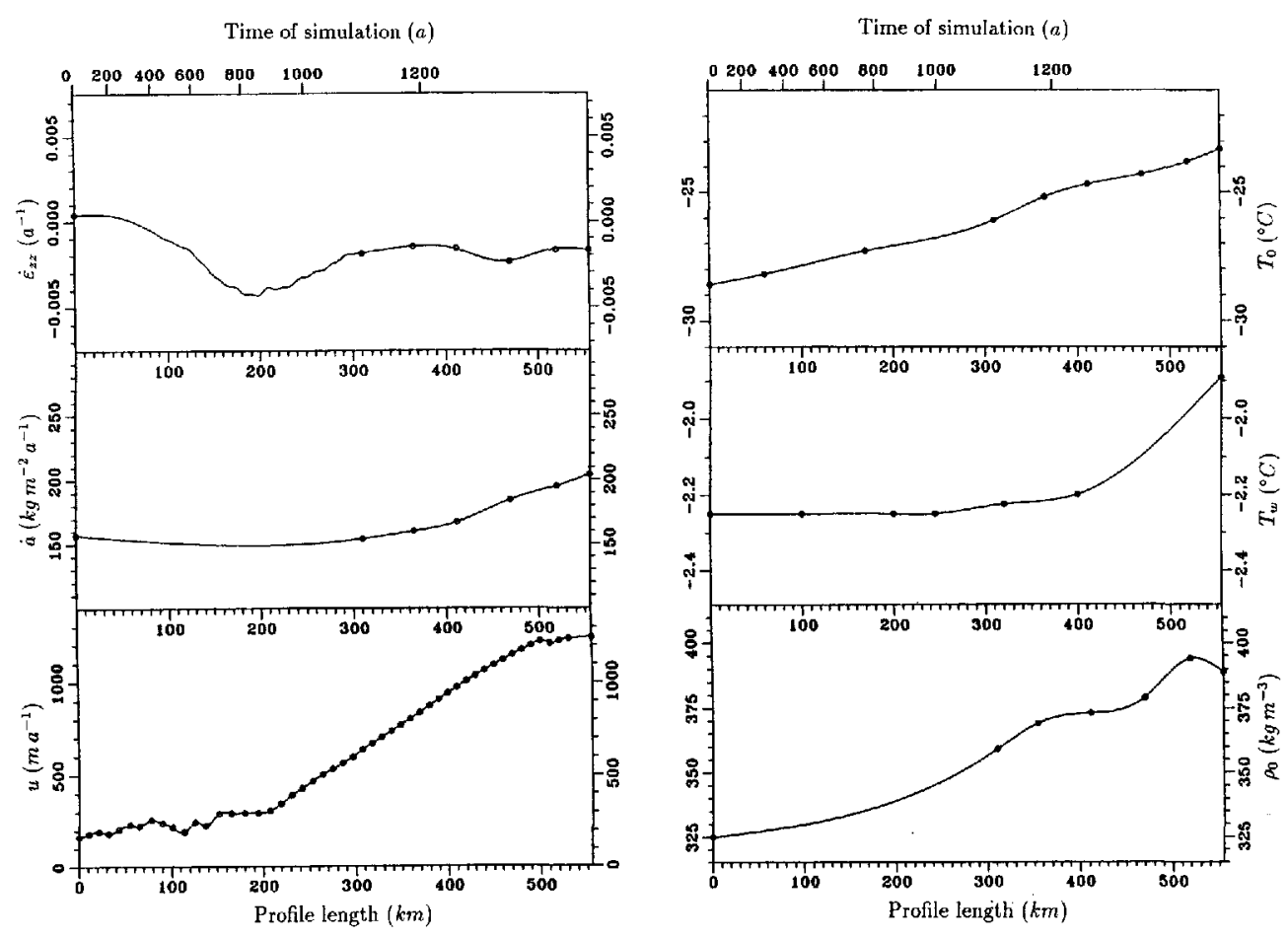

Fig. 3. Input data for the thermal model (references in the text). (Circles indicate results from measurements at distinct geodetic points along the calculated flowline. The solid line is the result of a spline interpolation at equidistant grid points. In the case of vertical strain rate, the values between 0 and $100 \mathrm{~km}$ were calculated from Equation (20), from 100 to $300 \mathrm{~km}$ from Equation (21).

the area between Henry Ice Rise and Berkner Island, where the ice flows through a narrow confined channel with strong lateral shear. The vertical strain rate decreases from $-1.0 \times 10^{3} \mathrm{a}^{1}$ to $-4.3 \times 10^{-3} \mathrm{a}^{-1}$, which is caused by the large decrease in metcoric icc thickncss from 830 to $330 \mathrm{~m}$ over a distance of about $90 \mathrm{~km}$. After $200 \mathrm{~km}$ of profile, the influence of Henry Ice Rise and Berkner Island is passed and the ice spreads due to horizontal divergence. This effect can also be recognized in the velocity profile that rapidly increases north of Henry Ice Rise.

The strong dccrease in meteoric ice thickness is partly compensated by the accumulation of marine ice. The amount of freezing and mclting, which alrcady occurs in the northern part of the ice shelf, was calculated in the arca of marine ice from Equation (22) and in areas of no marine ice from Equation (15). The ice thickness and the calculated freezing/melting rate is shown in Figure 4. The ice-thickness profile is typical for ice shelves. Starting with a large ice thickness of more than $1000 \mathrm{~m}$ near the grounding line, the ice thins along its flow out to sea. After about $100 \mathrm{~km}$, the process of basal freezing influences the mass balance. The maximum amount of freczing occurs at approximately $150-180 \mathrm{~km}$ of profile, the northern edge of Henry Ice Rise. Here, freezing rates of $2 \mathrm{~m} \mathrm{a}^{-1}$ are calculated. 'The area extends to about $260 \mathrm{~km}$ length, wherc an intermediate regime is reached and neither significant freexing nor melting dominate. The increase in meteoric ice thickness, which is caused by snow accumulation, is compensated due to thinning by strain. After $450 \mathrm{~km}$, a melting-profile regime dominates. The melting rate increases continuously to a value of $-3 \mathrm{ma}^{\prime}$ until it decreases again to a value of $2 \mathrm{ma}^{-1}$ near point 61 . Considering the error estimate of about $\pm 0.5 \mathrm{~m} \mathrm{a}^{-1}$, this value confirms with the investigation of basal melting from three independent experiments in the same region (Grosfeld and others, in press). Here, a mean melting rate of $-1.4 \pm 0.5 \mathrm{ma}^{-1}$ could be determined.
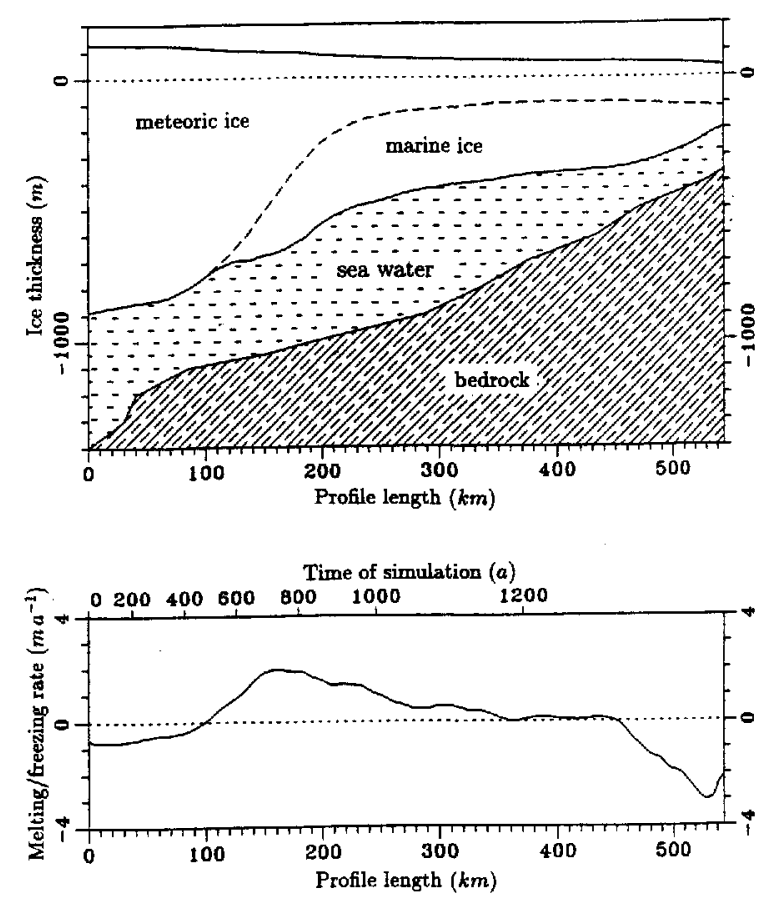

Fig. 4. Ice thickness and meltinglfreezing rate (positive values: freezing) along the flowline through the central part of FRIS. Sea-bottom topography in the upper plot is taken from Pozdeyev and Kurinin (1987). 
The thermal model for this flowline was used with the described boundary values and conditions. The marine layer was divided into a slushy layer and an old desalinated part. The maximum thickness, the slushy layer could achicve, was set $50 \mathrm{~m}$. For marine ice at thicknesses greater than $50 \mathrm{~m}$, the ice nearest the boundary with the meteoric ice becomes consolidated. This is in agreement with an increasing sensible softening in the lower $35 \mathrm{~m}$ of the ice shelf found by Engelhardt and Determann (1987) from hot-water drilling at point 335 . They explained this by a non-consolidated layer of slush. For the model, this layer was enlarged to $50 \mathrm{~m}$ to include the full consolidation and desalination of the slushy layer to the so-called old marine ice. The result of the thermal model with scaled dimensions in depth is shown in Figure 5.

The change in temperature-depth profile with simulation time and hence with distance along the flowline shows an extreme influence by basal freexing. $\mathrm{Lp}$ to $100 \mathrm{~km}$, a typical cubic profile indicating melting conditions was calculated. In the area of basal accretion, this profile changes into an S-shape with about $40 \%$ of the icc column showing temperatures between $-2.25^{\circ}$ and $-6.0^{\circ} \mathrm{C}$. The thermal conductivity of the slushy layer is about one-third lower than that of pure ice. A comparison with a thermal model neglecting the salinity and temperature-dependent thermal ice properties has been made. The change of temperature gradient in the lowest $50 \mathrm{~m}$ is during its building process steeper than in the case of a slushy layer, which demonstrates the absence of the isolating slush.

The relatively warm temperatures influence the thermal properties in large parts of the marine ice during the main basal freezing. In the intermediate part from $360 \mathrm{~km}$ onward, conductive heat transports are the major processes. The steep temperature gradient at the interface from meteoric to marine ice weakens and the marine ice gets colder. From $450 \mathrm{~km}$ of the profilc, the temperaturc-depth function is significantly influenced by basal melting. Over a distance of about $30 \mathrm{~km}$, the slushy layer melts and the almost isothermal profile with temperatures between $-2.0^{\circ}$ and $-4.0^{\circ} \mathrm{C}$ vanishes. The temperature-depth profile changes into a cubic profile, where the basal melting erodes the warmest part of the ice column and reduces its mean temperature.

In Figure 6, single calculated tempcrature profiles at distances of $25 \mathrm{~km}$ along the flowline and a comparison with measured profiles are shown. In this plot, the influcnce of basal accretion can easily be recognized. In the area of main basal freezing (profile at $175 \mathrm{~km}$ distance) the temperature-depth gradient changes to an almost isothermal profile with tempcratures between $-2.315^{\circ}$ and $-2.415^{\circ} \mathrm{C}$ over a depth range of $180 \mathrm{~m}$. With decreasing basal frcezing, the temperature gradient increases and changes into a cubic one in the area of basal melting near point 136 . The calculated profiles can be compared with measured data at two different sites. At point 236, the model shows colder temperatures than the measured data in the depth range of $20-270 \mathrm{~m}$. The maximum temperature difference of $-1.31^{\circ} \mathrm{C}$ occurs at $140 \mathrm{~m}$ depth. Below $270 \mathrm{~m}$, both data sets fit close together. There are several reasons for the difference between the calculated and measured data. On the one hand, the boundary valucs and the ice thickness depend very much on the estimated flowline and can only give an approximation of the real history of ice flow. On the other hand, the two-dimensional calculation docs not include the influence of the large crevassed zone in the central part, which probably is directly correlated with the thermal regime. Lastly, the measured temperature data themselves contain different possibilities for a non-steady state at the end of the field season 1991-92. Since ice-core drilling transports warm temperatures from the lower part of the ice shelf into the upper ice layers, the drillhole warms up, causing a disturbance in the steady-state temperature-depth profile. A comparison of the temperaturc data at point 236 with that at point 61 shows that the temperatures at $110200 \mathrm{~m}$ depth are $0.3^{\circ} \mathrm{C}$ warmer at point 236 than those at point 61 . From heat-conduction processes between the cold meteoric and the warm marine ice, an additional warming can be expected on the track from points 236 to 61 . Therefore, the actual temperatures at point 236 are probably lower than measured, and closer to the modclcd profilc than suggested by the measurements. Because of these reasons, the calculated temperature profile can be taken to be in agreement with the measured data.

The temperature profile at point 61 fits closer the results of the simulation. Over the whole depth range, the measured data can be reconstructed to the calculated values. The influence of bottom accretion has faded away and the effect of basal melting forms a cubic temperature profile with the same basal temperature gradient.

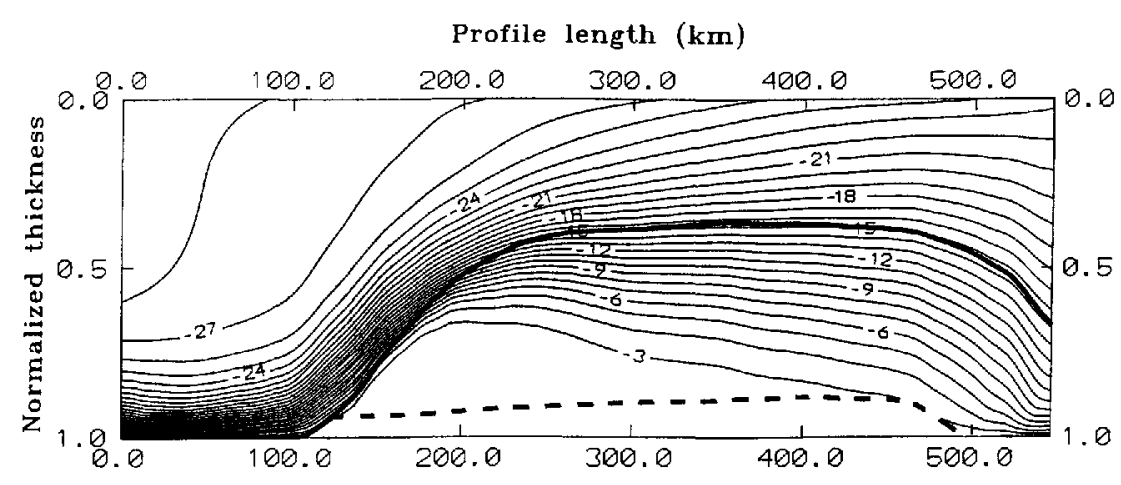

Fig. 5. Steady resull of the two-dimensional thermal model through the central part of FRIS as a function of normalized ice thickness and profile length. Contour lines with a spacing of $-1^{\circ} \mathrm{C}$. The boundaries between meteoric to marine ice and the normalized thickness of the slushy layer are indicated by heavy and broken lines, respectively. 


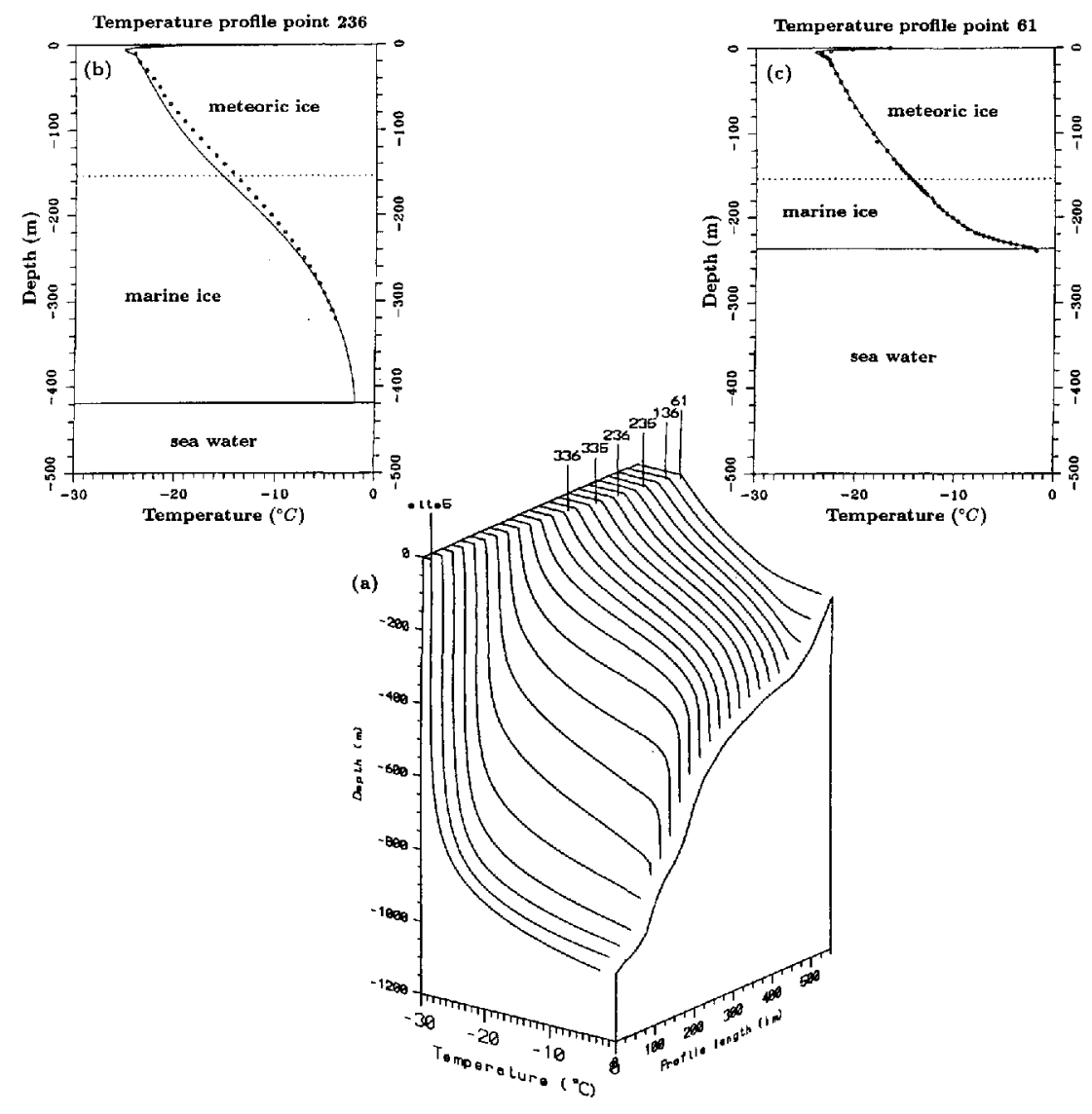

Fig. 6. a. Calculated temperature-depth profiles in a distance of $25 \mathrm{~km}$ along the flowline. The positions of geodetic points are marked. $b, c$. A comparison with measured temperature-depth profiles at point 61 and point 236 (Oerter and others, $1992 b)$ is shown.

\section{CONCLUSION}

Within the international Filchner-Ronne Ice Shelf Programme, we investigated the temperature depth profile by means of hot-water drillings and developed a two-dimensional thermal model to calculate the influcnce of the large bottom accretion and building of a basal layer of up to $400 \mathrm{~m}$ marine ice in the contral part. The temperature-depth profile was measured at the ice-edge region of FRIS and shows a typical cubic profile consistent with the melting base. The influence of basal frcczing in the central part has vanished at this location, and differences in the thermal properties of meteoric and marine icc could not bc rccognized. $\Lambda$ comparison with a temperature depth profile measured $150 \mathrm{~km}$ upstream in a drillhole by Ocrter and others (1992b) shows a significant influence due to bottom freezing. The profile changed into an S-shape form, caused by the heat input from the accretion process. For simulating the temperature regime on a flowline through the central part and for the reconstruction of the measured data, a twodimcnsional thermal model was developed. The subdivision of the ice column into meteoric and marine parts, which consisted of an older desalinated layer and a slushy bottom layer, was achieved by considering thermal properties depending on salinity and temperature in marine ice, especially in the slushy bottom layer. The time-dependent calculation was computed by means of FD methods with normalized depth and time derivatives.
Boundary values were taken from geophysical, geodetic, glaciological and oceanographic data, and models of the FRIS region.

The model results show a strong influence of basal accretion on the temperature field in the central part. Basal freczing rates of up to $2 \mathrm{ma}^{l}$ were found northeast of Henry Ice Rise as a result of mass-balance calculations. In the area of maximum freezing rate, the temperaturedepth profile changes from a cubic one into an S-shaped profile with almost isothermal conditions over a depth range of more than $180 \mathrm{~m}$. About $40 \%$ of the ice column was dominated by temperatures between $-2.25^{\circ}$ and $-6.0^{\circ} \mathrm{C}$. About $100 \mathrm{~km}$ from the ice edge, melting occurs and erodes the relativcly warm basal icc. A comparison of measured and calculated data shows convincing results.

Obviously, the thermal regime of the Filchner-Ronne Ice Shelf is significantly influenced by the amount of basal freezing, which finally affects the flow properties of the whole ice shelf and hence its dynamics.

\section{ACKNOWLEDGEMENTS}

The authors are very grateful to Miss M. Jonas, who presented this paper during the VISAG symposium because both authors were unable to attend the meeting. Funding by the Deutsche Forschungsgemeinschaft (DFG-TH168/20-2, DFG-BL307/1-1) and the Land Nordrhein-Westfalen is gratefully acknowledged. 


\section{REFERENCES}

Blindow, N. 1994. The central part of Filchner Ronne Ice Shelf, Antarctica: internal structures revaled by $40 \mathrm{MH}$. monopulse RES Am. Glaciol., 20 see paper in this volume!

Carslaw, H.S. and J. C. Jaeger. 1959. Conduction of heat in solids. Second edition. Oxford, Clarendon Press.

Crabtree, R. D. and C.S. M. Doake. 1986. Radio-echo investigations of Ronne Ice Shelf. Ann. Glaciol, , 8, 37-41.

Crary, A.P. 1961. Glaciological regime at Little America Station, Antarctica. 7. Geohor. Res, 66 3), 871-878.

Crary, A. P., E. S. Robinson. H. F. Bennett and W. W. Boyd, Jr. 1962. Glaciological regime of the Ross Ice Shelf. 7. Geophys. Res., 67(7), $2791-2807$.

Determann, J. 1991. Numerical modelling of ice shelf dynamics. Antarct $S_{c i,}, 3(2), 187 \quad 195$.

Drewry, D.J.. ed. 1983. Antartica: glaciological and geophysical folio. Cambridgc, University of Cambridge, Scott Polar Research Institute.

Engelhardt, H. and J. Determann. 1987. Borehole evidence for a thick layer of basal ice in the central Ronne Ice Shelf. Nature, 327 6120 ), 318-319.

Fahrbach, E., M. Knoche and G. Rohardt. 1991. An estimate of water mass transformation in the southern Weddell Sea. Marine Chem., 35, $25-44$.

Foldrik, A and T. Kuinge 1974. Conditional stability of sea water at the freezing point. Dekp-Sea Res., 21 (3), 169-174.

Foldwik, A., T. Gammelsrod, N. Slotsvik and T. Tørresen. 1985. Oceanographir conditions on the Weddell Sca Shelf during the German Antarctic Fxpedition 1979/80. Polar Res., 3(2), 209-226.

Graf, W. and 6 others. 1991. Isotopic and chemical investigations of 10 in firn cores from the castern part of Ronne Ice Shelf, Antarctica. In Miller, H. and H. Oerter, eds. Filchner-Ronne-Le-Shelf-Programme, Report 1o. 5, Bremerhaven, Alfred-Wegener-Institute, 45-53.

Grosfeld, K. 1992. Untersuchungen zu Temperaturregime und Massenhaushalt des Filchner-Ronne-Scholfeises. Antarktis, unter besonderer Berucksichtigung von Anfrier- und Abschmelzprozessen. (Disscration, Institut für Geophysik, Westf. Wilhclms-Universität Münster.

Grosfeld. K., N. Blindow and F. Thyssen. In press. Bottom melting on Filchner Ronne Ice Shelf, Antaretica, using different measuring terhniques. Polarforsching, 62(213)

Hellmer, H. H. and D.J. Olbers. 1989. A two-dimensional model for the thermohaline circulation under an icc shell. Antart. Sa., 1/4;, $325-336$.

Hcllmer. H. H. and D.J. Olbers. 1991. On the thermohaline circulation beneath the Filchner-Ronne Ice Shelf. Antarct. Sci, 3(4), 433-442.

Herron. M. M. and C.C. Langway, Jr. 1980. Firn densification: an cmpirical model. 7. Giaciol., 25(93), 373385.

Jenkins, A. 1991. A onc-dimensional model of ice shelf ocean interaction. J. Gophys. Res., 96(C11), 20,671-20,677.

Kipfstuhl, J. 1991. Zur Entstehung von Lnterwassereis und das Wachstum und die Energiebilanz des Meereises in der Atkabucht, Antarktis. Ber. Polarforsch., 85. Bremerhaven. Alfred-WegencrInstitut.

Kipfstuh], J. and H. Oerter. 1991. Feldglaziologische Arbeiten. In Miller, H. and H. Ocrter, eds. Ber. Polarforsch., 86, 6971. Bremerhaven. Alfred-Wegener-Institut.

Lange, M. A. and D. R. MacAyeal. 1988. Numerical models of steadystate thickness and basal ice configurations of the central Ronne Ice Shelf, Antarctica. Amm. Glaciol., 11, 64-70.

Lewis, E. L. and R.G. Perkin. 1986. Ice pumps and their rates. 7. Geoph's. Res., $91(\mathrm{Cl} 10), 11,756-11,762$.

MacAveal, D. R. and R.H. Thomas. 1986. The effect of basal melting on the present flow of the Ross Icc Shelf, Antarctica. 7. Glaciol, $32110: 72-86$.

Maykut. G. A. and N. Untersteiner. 1971. Some results from a timedependent thermodynamic model of sea ice. 7 . Geophys. Res., 76(6), $15 \overline{50} 1575$

Mercer, J. H. 1978. West Antarctic ice sheet and $\mathrm{CO}_{2}$ greenhouse effect: a threat of disaster. Nature, 271 5643$), 321325$.
Möller, D., B. Riedel and B. Ritter. 1992. Strain and velocity determination on Ronne Icc Shelf: In $\mathrm{H}$. Oerter, ed. Filchner-RonneIce-Shelf-Programme, Report No. 6, Bremerhaven, Alfred-WegenerInstitute, 61-68.

Morgan, V. I. 1972. Oxygen isotope evidence for bottom freczing on the Amery Icc Shclf. Nature, 238(5364), 393-394

Morris, F. M. and D. G. Vaughan. 1991. Glaciological measurements on the South Ronne Ice Shelf. In Miller, H. and H. Oerter, eds. Filchner Ronne-Ice-Shelf-Programme. Report No. 5, Bremerhaven, Alfred-Wegener-Institute, 37-44.

Oerter, H. and 6 others. 1992a. Evidence for basal marine ice in the Filchner -Ronne Ice Shelf. Nature, 358(6385), 399-401.

Oerter, H., C. Drücker, J. Kipfstuhl, U. Nixdorf and W. Graf, 1992b. The Filchner IV campaign and the $320 \mathrm{~m}$ deep ice core B15. In H. Oerter, ed. Filchner-Ronne-Ice-Shelf-Programme, Report No. 6 , Bremerhaven, Alfred-Wegener-Institute, 47-53.

Paterson, W.S. B. 1981. The physics of giaciers. Second edition. Oxford, etc., Pergamon Press.

Pozdeyer, V.S. and R.G. Kurinin. 1987. New data on the ice-sheet morphology, bodrock and bottom rolicf in the southern part of the Weddell Sea basin (Wesı Antarctica). Antarkika, 26, 66-71. (In Russian.)

Ritter, B. and A. Karsten. 1991. Gcodäsic. In Miller, H. and H. Ocrter, eds. Ber. Polarforsch., 86, 50-57, Bremerhaven, Alfred-WegenerInstitut.

Robin, G.de Q. 1955. Ice movement and temperature distribution in glaciers and ice sheets. 7. Glacinl., 2(18), 523-532.

Robin, G.de Q 1979. Formation, flow, and disintegration of ice shelves. 7. Glaciol, 24 90$), 259-271$.

Robin, G.deQ, C.S.M. Doake, II. Kohnen, R.D. Crabtree, S.R. Jordan and D. Möller. 1983. Regime of Filchner-Ronne Ice Shelves, Antarctica. Nature, 302(5909), 582-586.

Sanderson, T.J.O. and C. S. M. Doake. 1979. Is vertical shear in an ice shelf negligible? 7 . Claciol., 22 87 ), 285-292.

Scheduikat, M. and 1).J. Olbers. 1990. A one-dimensional mixed layer model beneath the Ross Ice Shelf with tidally induced vertical mixing. Antart. Sci., 2(1), 29 42.

Schwerdffeger, P. 1963a. Thcoretical derivation of the thermal conductivity and diffusivity of snow. International Association of Hydrological Sciences Publication, 61, 75-81.

Schwerdtfeger, P. $1963 \mathrm{~b}$. The thermal propertics of sca ice. 7 . Glaciol., $4(36), 789-807$.

Swithinbank, C., K. Brunk and J. Sievers. 1988. A glaciological map of Filchner-Ronne Ice Shelf, Antarctica. Ann. Glaciol., 11, 150 155.

Thyssen, F. 1986. The contral part of the Filchner/Ronne Ice Shelf. In H. Kohnen, ed. Filctone-Ronne-Ice-Shelf-Programme, Raport No. 3, Bremerhaven, Alfred-Wegener-Institute, 81-83.

Thyssen, F. 1988. Special aspects of the central part of Filchner-Ronne Ice Shelf, Antarctica. Ann. Glaciol, 11, 173-179.

Thyssen, F, A. Bombosch and H. Sandhäger. 1992. Elevation, ice thickness and structure mark maps of the central part of Filchner Ronne Ice Shclf. Polarforschung, $\mathbf{6 2}(1)$.

Untersteiner, N. 1964. Calculations of temperature regime and heat budget of sea ice in the central Arctic. 7. Geophys. Res., 69(22), 4755-4766.

Van der Veen, C.J. 1985. The West Antarctic icc sheet: the need to understand its dynamics. In Van der Veen, C.J. and J. Oerlemanns, ids. Dynamics of the West Antarctic ice sheet. Dordrecht, ctc., D. Reidel Publishing Companv, 1-16.

Van Dusen, M.S. 1929. Thermal conductivity of non-metallic solids. In Washburn, E. W. ed. International critical tables of numerical data: physics, chemistry and techology, 5, New York, MacGraw Hill, 216-217.

Wclander, P. 1977. Thermal oscillations in a fluid heated from below and cooled to freezing from above. Dynamics Atmos. Oceans, 1, $215 \cdots 223$.

Yen, Y.C. 1981 . Revicw of thermal propertics of snow, ice, and sca icc. CRREL Rep. 81-10.

The accuracy of references in the text and in this list is the responsibility of the authors, to whom queries should be addressed. 